\title{
The Globalization of Sexuality: An Interview with Jon Binnie
}

\author{
Joseli Maria Silva \\ (Grupo de Estudos Territoriais / Universidade \\ Estadual de Ponta Grossa, Brasil) \\ Marcio Jose Ornat \\ (Grupo de Estudos Territoriais / Universidade \\ Estadual de Ponta Grossa, Brasil)
}

This year Brazil hosted the World Meeting of the United Nations about Sustainable Development, bringing up the need of thinking about world diversity through solidarity, cooperative and articulated actions. Social existence occurs in an inevitably connected way. In spite of being negleted by social theory and global institutions, sexuality is an important element of globalization analysis. Thinking about features and ways of connections between different places is one of Jon Binnie' s concerns, who published the book The Globalization of Sexuality in 2004. This exciting researcher argues that the political and economical processes are also cultural ones, bringing sexuality topic to debates around international relations.

Jon Binnie recevied his $\mathrm{PhD}$ in 1997 at the University College London with the thesis entitled 'A Geography of Urban Desires: Sexual Culture and the City'. Over the years he became one of the most influential Geographers in the area of sexuality and today he is Reader in Human Geography in the School of Science and Environment at Manchester Metropolitan University and between 2006 and 2009 he was also Director of the Manchester Institute of Social and Spatial Transformations.

Author of several books which inspire most of us Latin-American sexuality reseachers, now he joins us, in a collaborative way, to enrich the Latin-American Journal of Geography and Gender with his ideas. His scientific course, like his political positions are the focus of this interview. And we hope it can inspire other Latin geographers to explore the huge field of sexualities, the same way it happened to us.

Joseli Maria Silva e Marcio Jose Ornat: The book 'The Globalization of Sexuality', published in 2004 criticizes the ethnocentrism of queer theory and the idea of gay universality. It also incorporates the need to consider elements such as class, race and economy to LGBT and queer studies. What are the opportunities for solidarity actions between different places through the incorporation of these elements to the idea of sexuality?

Jon Binnie: One of the main concerns in my work has been the examination of the connection between the politics of sexual desire, and broader socioeconomic and political concerns. I wrote 'The Globalization of Sexuality' out of frustration with mainstream accounts of globalization and transnationalism that often ignored sexuality as a significant dimension of global and transnational politics. I was also motivated by the neglect of sexuality within heteronormative writing on globalisation and transnationalism within feminist international relations and feminist geography. Moreover I was frustrated by the ways in which the economic dimensions had often been neglected within research on sexualities, and the way that sexual politics has often been framed as 'merely cultural' (BUTLER, 1997). Events such as IDAHO (International Day Against Homophobia and Transphobia) and the Gay Games promote the notion of global LGBT solidarity. Many pride events for instance now have an international, or global focus, and may self-consciously promote global LGBT solidarity. For instance the pride event in Munich this year had the theme 'Fight for Global Rights: Solidarity Knows no Borders'. While these forms of solidarity across borders may be very powerful and important symbolically in offering support to LGBT struggles elsewhere, we need to remain alert to the power differences that frame transnational connections in relation to sexualities, and the danger that such forms of solidarity may have harmful effects, by reproducing hegemonic geotemporal notions of progress, Western paternalism, and ethnocentric conceptions of sexual dissident cultures. While it is of course important to challenge homophobia and transphobia in all contexts, we need to 
recognition that this resistance can sometimes have harmful effects, particularly if it fails to recognise the importance of race and class. As legal scholars such as Leslie Moran have noted, well-meaning policing campaigns against homophobic hate crime can further criminalise working class and ethnic minority youth. We therefore need to interrogate the intersectional politics of solidarity actions between actors located in different places. The transnational and intersectional politics of solidarity bring to the fore issues of scale, territoriality, networks and relational politics that have been pioneered by Michael Brown and Stephen Legg. Despite valuable work by Richard Phillips on the sexual politics of imperialism, much more work needs to be done to decolonise the geographies of sexualities. As Natalie Oswin (2008) has argued, race has often been sidelined within the geographies of sexualities, and there is still a distinct paucity of work and perspectives from queer geographers of color. Furthermore, there is little work that examines the intersectional politics of race and class. Andy Tucker's (2009) work is therefore innovative by interrogating the intersectional politics of race and class into his examination of the social-economic geography of queer visibilities in Cape Town. While research on sexualities have been incorpated within Social and Cultural Geography and to a lesser extent within Political Geography, it is still the case that Economic Geography remains largely immune to research on sexualities. The relationships between economics and sexualities have been perhaps most substantially researched within research on sex work - with Phil Hubbard pioneering this field. While research on sex work, and the sexual geographies of gentrification, regeneration and tourism explicitly examines the interconnections between the sexual and the economic, work on the geographies of sexualities is often labelled as Cultural Geography as opposed to Economic Geography. Despite Linda McDowell's extensive research on gender, sexuality and the workplace, the sexual politics of work remains largely relatively understudied compared to the sexual politics of consumption.

JMS e MJO: In 'Coming out of Geography', published in 1997 in the Journal Environment \& Planning $D$, there is an appeal to think about the epistemology and methodology of Geography through the 'queer'. What are the advances in the production of geographical knowledge that can be pointed in this way?

JB: I wrote the paper 'Coming Out of Geography' to try and understand and challenge the marginalisation of sexuality within Anglo-American geography in the mid-1990s. Despite the cultural turn and the enthusiasm for postmodern approaches in Anglo-American Human Geography at the time which had foregrounded notions of difference and diversity within geographical knowledge, sexuality was one aspect of diversity and experience that was largely absent from these debates at the time, hence the importance of David Bell's (1991) intervention 'insignificant others'. This paper argued at that lesbians and gay men were the least visible Others in Geography. 'Coming Out of Geography' was heavily influenced by feminist geographical critiques of the gender politics of knowledge production in human geography (MCDOWELL, 1992; MONK and HANSON, 1982; Rose, 1993). At the same time it sought to critique heterosexism and esentialism within some feminist work in this area. I argued that in order to understand the marginalisation of sexuality within human geography (compared to other disciplines such as Anthropology, History, Sociology and Cultural Studies that appeared to be much more receptive to work on sexuality at the time), it was necessary to recognise the disciplinary heritage of Anglo-American geography with the proximity to the natural sciences and the related dominance of positivism; as well as the heroic masculinism associated with field work. The paper demonstrates the ambivalent relationship between queer and feminist research within human geography. Queer geographies were enabled and facilitated by the growth of feminist geography, but also constrained by the latter's heterosexism. It would be easy to frame the development of the geographies of sexualities in terms of a narrative of progress. Indeed, since the mid 1990s the growth of publication in this area has been spectacular. Mainstream high profile journals such as 'Society and Space' and 'Social and Cultural Geography' regularly feature work on sexuality. For instance Natalie Oswin has recently edited a special virtual theme issue of 'Society and Space' on sexuality and space. Sexuality now regularly features in courses in Anglo-American human geography, particularly within Social and Cultural Geography. However I do not believe it is helpful to mobilise a progress narrative here in thinking through methodologies and epistemologies in relation the geographies of sexualities. As David Bell (2011) has argued it is important to acknowledge what gets lost in the progress narratives of the development of the geographies of sexualities. He has suggested that accounts of the development of the geographies of sexualities can sometimes reproduce a triumphalist narrative. Such accounts are often selective and written from the geographical centres of the discipline 
and overlook the peripheries (though see JONSTON and LONGHURST, 2010). Anoop Nayak and Alex Jeffrey (2011) have argued, the geographies of sexualities challenge to the way that geographers do research. However I would argue that this challenge to the methodology and epistemology of Geography often remains blunted, and that geographies of sexualities have yet to impact significantly on the 'practising' of geography. In terms of methodology and epistemology it is still rare to read of accounts that foreground sexuality in the research process with Gavin Brown's (2008) essay on the material practices of public sex in toilets being an important exception. Reflecting back on the 'Coming Out of Geography' essay I note that I have still to write more directly and explicitly on sadomasochism and that there is still very little research on sadomasochism within the geographies of sexualities, with for instance Eleanor Wilkinson's (2009) essay being a notable exception. The critique of heteronormative understandings of gender has been a feature of queer geographies, though transgendered perspectives on space have been sparse (though see DOAN, 2007; BROWNE, NASH and HINES, 2010; NAMASTE, 1996). Likewise, other than David Bell's (1994) discussion of bisexual space and Hemmings' (1995) essay on bisexuality, there have been few examinations of bisexuality within the geographies of sexualities. There are many significant gaps in the geographies of sexualities for instance in terms of children's geographies, the lifecourse and intergenerationality. Furthermore I would like to suggest that in some respects, institutional constraints on research in this area may in fact be worse now compared to the 1990s. For instance the growth of health and safety and ethical audit cultures within UK higher education may stifle innovation in methodological practice, and rationalise and institutionalise squeamishness about sexual and embodied knowledge. Institutional pressure to conduct research that is applied and that has an enterprise function may inhibit research that is seeking to examine sexualities in a more challenging, innovative or critical way. Moreover, as Joseli Maria Silva (2011) has powerfully and eloquently argued, it is important to recognise the transnational dimensions of knowledge production in the geographies of sexualities, the dominance of the English language, and citation practices whereby work produced in some geographical contexts is recognised as having greater value than work produced elsewhere (BINNIE, 2011).

JMS e MJO: The book 'Pleasure Zones: Bodies, Cities, Spaces', published in 2001 calls attention to the body and its spatial implications. It also carries a diverse set of approaches about this relationship. Did this book contribute to the expansion of the body approach in the queer Geography perspective?

JB:I see a strong connection between the geography of the body and queer geography. I wrote my PhD at UCL in the early 1990s at the same time as Julia Cream who was researching the effects of the technology of the pill on the sexed body. We often discussed the limits theoretically and methodologically about writing and researching about the sexed and sexualised body. Indeed Julian Cream's essay on the sexed body and Linda McDowell's essay on the body in the workplace were key contributions to Mapping Desire. The idea for Pleasure Zones came from the AAG meeting in San Francisco 1994, when David and I met with Robyn Longhurst for the first time. later that year I met Robin Peace at the Regional Conference of the International Geographical Union in Prague. Pleasure Zones is an example of the pleasures of transnational solidarity in relation to the geographies of sexualities, but also an example of the difficulties of such projects. Working on the book together provided mutual support for scholars working in academic contexts that were not always supportive of feminist and queer work that sought to question the disembodied nature of geographical inquiry. The book was thereby produced out of a desire to escape intellectual isolation we felt. Moreover the book sought to address the politics of location and the marginalisation of geographers from Aotearoa/New Zealand relative to the northern hemisphere-dominated Anglo-American Geography. However the book was also a reflection of the barriers of physical space despite virtual contact and email correspondence. Face-to-face contact is so important in such projects, and the lack of non-virtual contact at times hampered progress on the book. If we had to communicate in different languages this collaboration would obviously have been much more difficult. The tyranny of distance has meant that it has been hard to build on this collaboration despite the relatively priviliged positions that we hold within the academy. Much writing about the body in geography is at an abstract level, whereas Robyn Longhurst's work on the pregnant and the fat body has always sought to push the boundaries methodologically in terms of 'embodying' geography. It can sometimes be harmful to label or judge some research as being queerer than others. Yet I certainly do think that Robyn's research on embodiment has been groundbreakingly queer in its resistance to epistemological norms within geography 
(including feminist geography) that disavow the messy materiality of the body. In the introduction to 'Pleasure Zones', Robyn Longhurst, Robin Peace and I argued that: geography as a discipline has been notably reluctant in studying pleasure other than as a clean-cut, pure psychoanalytical conception of desire. Pleasure, as a crucial part of the materiality of embodiment, deserves serious, critical, but also pleasurable attention (2001, p. xi). The essays in 'Pleasure Zones' sought to examine the limits in the reproduction of embodied geographies as opposed to geographies of the body. A decade on from 'Pleasure Zones' there are many examples of work that are pushing those boundaries, and taking things much further in thinking about embodiment in new and exciting ways - for instance the work of Bethan Evans, Rachel Colls and Robyn Longhurst on the critical geographies of fatness. However I would argue that it is still easier to write about the body in an abstract, disembodied sense. There are also personal and professional costs in embodying research which explain the ongoing disembodied nature of geographical knowledge.

JMS e MJO: In 2000 the book 'The Sexual Citizen' published with David Bell explores the sexual rights from space perspective. Did this idea contribute to the dialogue between Geography and other fields of social sciences and queer theory?

JB: 'The Sexual Citizen' was written in the context of the social and legal transformations in the status of lesbians and gay men in the UK in the 1990s and the campaigns for an equal age of consent, same sex marriage and the right to serve in the military. Writing the book, David Bell and I sought to make sense of these transformations in the context of academic debates on queer theory and the geographies of sexualities. I would like to think that 'The Sexual Citizen' has helped to further a dialogue between Geographers and other social sciences in relation to the spatial dimensions of sexual politics. However this dialogue was already well established in the UK particularly with queer and feminist legal scholars such as Leslie Moran, Davina Cooper and Carl Stychin. Davina Cooper has been engaged with the politics of space and has published in geographical journals. Working on my $\mathrm{PhD}$ in the early 1990s necessitated the development of networks of support outside of Geography, and interdisciplinarity has been essential to my own work on the geographies of sexualities. Interdisciplinary work and support was particularly important during my $\mathrm{PhD}$ when I felt rather isolated. Both David and I have worked in interdisciplinary contexts. I used to work in an interdisciplinary School of Social Sciences at Liverpool John Moores University and used to teach Criminal Justice students as well as Geography students. David was based in Cultural Studies for many years before returning to Geography. We sought to further this dialogue with a special issue of 'Political Geography' on the geographies of sexual citizenship (BELL and BINNIE, 2006). Research collaborations have been invaluable sources of emotional support and friendship which have been particularly important in overcoming intellectual isolation.

JMS e MJO: In the text 'Researching transnational solidarities around LGBTQ politics in Poland: brief reflections', published in 2009, along with Christian Klesse, there is a concern to discuss ways of cooperation and political solidarity among places with different cultures. Does solidarity LGBT policies may occur between countries with a strong colonial past, as Latin America countries (colonized) and Western Europe countries (colonizers)?

JB: In the research project on transnational solidarities in LGBTQ politics in Poland that I have conducted with my colleague Christian Klesse (who works in Sociology at Manchester Metropolitan University) we have sought to map and understand the development of transnational activist networks with regard to equality marches in Poland since 2004. These marches such as those in Warsaw and Poznan have in some instances been banned by city authorities, and have often been met by violent far right counter-protest. Our research has sought to understand the motivations of activists who were differently located within the transnational networks related to these events, and to examine how they understood the concept of solidarity and how it was practised within these networks. We have found that issues of age and generation have been significant in activist narratives of political solidarity - particularly in relation to discussions of conflicts related to gender and cultural difference (BINNIE and KLESSE, [forthcoming]). As I discussed earlier in relation to global sexual politics, notions of global, international and transnational solidarity can often mobilise problematic geo-temporal formations, and construct some nations as being more 'advanced' and 'progressive' in relation to others marked as 'backward'. Current debates on transnational solidarity in relation to LGBTQ politics have been led by postcolonial and queer of colour critiques. In

Joseli Maria Silva e Marcio Jose Ornat 
particular the work of Jasbir Puar (2006) and Jin Haritaworn (2008) has been to the fore in challenging the way in which LGBT politics can be folded into anti-Muslim discourse in contexts such as the United States, the UK, The Netherlands and Germany. In this context, solidarity is often problematically understood in a paternalistic way, as a form of rescuing or aiding the Other (BRACKE, 2012), which can serve to reproduce uneven relations of power and become a form of disciplining of the Other. Postcolonial theory has been productive in relation to discussions of sexual politics within Central and Eastern Europe, where the European Union has been critiqued as a neo-colonial actor disciplining accession states, and member-states in the periphery. As I have not yet studied the postcolonial sexual politics of transnational queer connections between Western Europe and Latin America, I am not best placed to comment on transnational political solidarities between Portugal and Brazil (though this is something I would be interested in researching collaboratively in future). My work with Christian Klesse on the geographies of transnational activist networks in relation to Poland has demonstrated to me the need to recognise the geographical specificity, and to challenge hegemonic geo-temporal constructions of East and West Europe. Working in different contexts always draws into focus the parochialism and limitations of theories developed in Anglo-American contexts.

JMS e MJO: In the text 'Trading places: consumption, sexuality and the production of queer space' published in 1995 in the book 'Mapping desire' there is a perspective to build an analysis that explores the economic relations and the production of sexualized spaces. How have sexual cultures been elements of appropriation by the market?

JB: As I mentioned earlier, work on the geographies of sexualities is often labelled as being part of Social and Cultural Geography as opposed to Economic Geography. This is despite pioneering work by Larry Knopp which focussed on the relationship between sexuality and capitalism through the analysis of economic processes such as gentrification. I was drawn to write about the economic dimensions of sexualised spaces for a number of reasons. During my undergraduate studies at Durham I specialised in Economic Geography and was inspired by the teaching of Ray Hudson on the politics of uneven regional development in the North East of England and Southern Europe. At this time I was energised by Doreen Massey's book 'Spatial Divisions of Labour', which demonstrated the significance of place and the gendered dimensions of labour. It opened up the whole field of gender for me intellectually, and I was very fortunate to be taught by Janet Townsend who encouraged me to attend an ERASMUS (European Union-funded) geography and gender workshop at the University of Amsterdam. It is certainly the case that sexual cultures have been appropriated by the market. However I would also argue that sexual cultures are promoted, or enabled by the market. The market both enables and constrains sexual cultures (indeed it is hard to imagine many aspects of human activity that have not been appropriated or colonised by the market in some shape of form). I have been intrigued by the way that lesbian and gay rights claims have often been wrapped in economic terms, even if these claims can sometimes appear far fetched (such as the claim that legal recognition of same sex partnerships in the UK would provide a boost to the British hospitality industry [STYCHIN, 2006]). Equally I have been fascinated by the way that lesbians and gay men have sometimes been represented as exceptionally, or excessively commodified or standard bearers for neoliberalism. In my work I have sought to challenge essentialist thinking concerning the supposed privileged economic status of gay men that tends to reproduce middle-class experience as gay experience. In the geographies of sexualities there is still much work to open up lines of enquiry that unsettle orthodoxies and normativities, while simultaneously challenging forms of queer theoretical purity and political practice.

\section{References}

BINNIE, Jon. Trading places: consumption, sexuality and the production of queer space. In: BELL, David; VALENTINE, Gill. Mapping desire. Geographies of sexualities. London: Routledge, 1995, p. 182 - 199.

BINNIE, Jon. Coming Out of Geography: towards a queer epistemology? Environment \& Planning D: Society \& Space, v. 15, p. 223-237, 1997.

BELL, David. Insignificant others: lesbian and gay geographies. Area, v 23, p. 323-29, 1991.

BELL, David. Bisexuality: a place on the margins. In WHITTLE, Stephen (ed.) The Margins of the City. Aldershot: Ashgate, 1994, p. 129 - 142.

BELL, David. 'O que foi, tera sido? A geografia a partir do queer. In: SILVA, Joseli Maria; SILVA, Augusto Cesar Pinheiro da (Eds.) Espaco, Genero e

Joseli Maria Silva e Marcio J ose Ornat 
Poder: Conectando Fronteiras, Ponta Grossa: Todapalavra, 2011, p. $201-214$.

BELL, David, BINNIE, Jon. The Sexual Citizen: Queer Politics and Beyond. Cambridge: Polity Press, 2000 .

BELL, David, BINNIE, Jon, HOLLIDAY, Ruth, LONGHURST, Robyn, PEACE, Robin. Pleasure Zones: Bodies, Cities, Spaces. New York: Syracuse University Press, 2001.

BINNIE, Jon. Sexuality, the erotic and Geography: epistemology, methodology and pedagogy. In: BROWNE, Kath; LIM, Jason; BROWN, Gavin (Eds.) Geographies of Sexualities: Theory, Practices and Politics. Aldershot: Ashgate, p. 29 - 38.

BINNIE, Jon. The Globalization of Sexuality. London, England: Sage, 2007.

BINNIE, Jon; KLESSE, Christian. 'Researching transnational solidarities around LGBTQ politics in Poland: brief reflections'. Interalia, n. 4, 2009. Disponível em: http://interalia.org.pl/en/artykuly/current_issue 2009 4/02 the manchester seminar.htm. Acesso em $23 / 0 \overline{6} / 20 \overline{1} 2$.

BINNIE, Jon and KLESSE, Christian. The politics of age, temporality and intergenerationality in transnational lesbian, gay, bisexual, transgender and queer activist networks, Sociology, forthcoming.

BINNIE, Jon; LONGHURST, Robyn; PEACE, Robin. Upstairs/downstairs - place matters, bodies matter. In: BELL, David, BINNIE, Jon, HOLLIDAY, Ruth, LONGHURST, Robyn, PEACE, Robin. Pleasure Zones: Bodies, Cities, Spaces. New York: Syracuse University Press, 2001, p. vii - xiv.

BRACKE, Sarah. From 'saving women' to 'saving gays': Rescue narratives and their dis/continuities. European Journal of Women's Studies, v. 19, p. $237-$ 252, 2012.

BROWN, Gavin. Ceramics, clothing and other bodies: affective geographies of homoerotic cruising encounters. Social \& Cultural Geography, v. 9, p. $915-932,2008$.

BROWNE, Kath; NASH, Catherine; HINES, Sally. Introduction: towards trans geographies, Gender, Place and Culture, v. 17, p. 573-577, 2010.
BUTLER, Judith. Merely cultural. Social Text, v. 52 53, p. 265-78, 1997.

DOAN, Petra. Queers in the American City: Transgendered perceptions of urban space. Gender, Place and Culture, v. 14, p. 57 - 74, 2007.

DOAN, Petra. The tyranny of gendered spaces reflections from beyond the gender dichotomy. Gender, Place and Culture, v. 17, p. 635 - 654, 2010.

HARITAWORN, Jin. Loyal Repetitions of the Nation: Gay Assimilation and the 'War on Terror'. DarkMatter, n. 3, <http://www.darkmatter101.org>, 2008.

MONK, Janice; HANSON, Susan. On not excluding half of the human in human geography. The Professional Geographer, v. 34, p. 11 - 23, 1982.

NAMASTE, Ki. Genderbashing: sexuality, gender, and the regulation of public space. Environment and Planning D: Society and Space, v. 16, p. 221 - 240, 1996.

NASH, Catherine.J. Trans geographies embodiment and experience. Gender, Place and Culture, v. 17, p. $579-595,2010$.

NAYAK, Anoop and JEFFREY, Alex. Geographical Thought: An Introduction to Ideas in Human Geography. London: Prentice Hall, 2011.

PUAR, Jasbir. Mapping US homonormativities. Gender, Place and Culture, v. 13, p. 67 - 88, 2006.

ROSE, Gillian. Feminism and Geography: The Limits of Geographical Knowledge. Cambridge: Polity Press, 1993.

SILVA, Joseli Maria. Geography and sexuality in Brazil: spatial and subverting epistemological orders. Paper presented at the European Geographies of Sexualities Conference, Hogeschool-Universiteit Brussel, September, 2011.

STYCHIN, Carl. 'Las Vegas is not where we are': Queer readings of the Civil Partnership Act'. Political Geography, v. 25, p. 899 - 920, 2006.

WILKINSON, Eleanor. Perverting visual pleasure: representing sadomasochism. Sexualities, v. 12, p. 181 - 198, 2009. 